\title{
Świat jako kloaka i udawanie sensu. Paliatywy w świecie prozy Thomasa Bernharda
}

Paweł Jasnowski

TEKSTY DRUGIE 2017, NR 2, S. 375-398

DOI: $10.18318 /$ td. 2017.2 .21

Każdy człowiek potrzebuje płaszcza, bo inaczej zamarznie zimą, a świat jest swego rodzaju zima. ${ }^{1}$

Thomas Bernhard

jak najszybciej dać nogę, uciec od tego wszystkiego, ratować swą skórę, ratować się, jak najszybciej dając nogę i uciekając od tego wszystkiego, ratować własną głowę, ratować własną osobowość, ratować własną naturę. ${ }^{2}$

Thomas Bernhard (K, s. 28)

1 T. Bernhard Spotkanie. Rozmowy z Kristą Fleishmann, przeł. S. Lisiecka, PIW, Warszawa 2010, s. 113.

2 Skrótem K oznaczam cytaty z powieści: T. Bernhard Korekta, przeł. M. Kędzierski, Czytelnik, Warszawa 2013. Poza tym posługuję się także następującymi skrótami: A - Autobiografie, przeł. S. Lisiecka, Czarne, Wołowiec 2011, B - Beton, przeł. E. Dyczek, M.F. Nowak, Atut, Wrocław 2001, BW - Bratanek Wittgensteina, przeł. M. Kędzierski, Oficyna Literacka, Kraków 1997, DM - Dawni Mistrzowie, przeł. M. Kędzierski, Czytelnik, Warszawa 2010, P - Przegrany, przeł. M. Kędzierski, Czytelnik, Warszawa 2002, T - Tak. Wyjadacze, przeł. M. Muskała, Czytelnik, Warszawa 2015, W - Wycinka, przeł. M. Muskała, Czytelnik 2011, WR - Wymazywanie. Rozpad, przeł. S. Lisiecka, W.A.B., Warszawa 2004, Z - Zaburzenie, przeł. S. Lisiecka, Czytelnik, Warszawa 2013.

\section{Paweł Jasnowski}

- judaista, krytyk, doktorant Instytutu Judaistyki UJ. Ostatnio publikował m.in: Perec i melancholia. Zarys geografii melancholicznej ("Teksty Drugie"). Swoje rozprawy, szkice i recenzje ogłaszał m.in. w „Pamiętniku Literackim”, „Kwartalniku Historycznym”, ,Znaku,,,Res Publice,",Akcencie," „Twórczości", "Tygodniku Powszechnym" i „Polityce." Kontakt: jasnowski.pawel@ gmail.com 
Jedyni przyjaciele, jakich posiadam, to umarli, którzy zostawili mi swoją literaturę, żadnych innych przyjaciół nie mam.

Thomas Bernhard (B, s. 33)

\section{Dla JowityJaszczyk}

\section{Palliare}

Na pierwszych stronach swego głośnego eseju Kultura jako źródło cierpień Zygmunt Freud powiada tak: „Ciężko jest znieść jarzmo życia - przynosi nam ono zbyt wiele bólu, rozczarowań, zadań, których nie sposób rozwiązać"3. Aby temu sprostać, pisze Freud, potrzebne są nam środki łagodzące, uśmierzające, bez których - powiada za Theodorem Fontane - w ogóle nie da się żyć ${ }^{4}$. Te autor Histerii i lęku dzieli na trzy rodzaje: środki odwracające uwagę, które pozwalają nam zagłuszyć nieszczęście, środki zastępcze, zmniejszające je, i środki odurzające, sprawiające, że na tę niedolę pozostajemy niewrażliwi ${ }^{5}$. Fontane określa je „konstrukcjami pomocniczymi”, Samuel Beckett, jak Freud, „środkami uśmierzającymi”. Jedną z takich konstrukcji jest opowieść, żywioł narracji, własne i cudze słowa. Piszący bywają tu zaskakująco zgodni: „Pisanie mnie chroni"7 , powiadał Georges Perec w Jesiennym gnocchi ${ }^{8}$. „Pisanie chroni mnie przed szaleństwem", mówił w Krakowie Kamel Daoud (autor gniewnej rewizji Obcego Camusa). „Zasadniczo piszę dlatego, że jest to sposób walki z brakiem szczęścia", odparł Mario Vargas Llosa Ricardo Settiemu.

Thomas Bernhard, pisarz osobny, dzielił tę samą, nieodpartą, jak się zdaje, potrzebę: szukania środków zaradczych. W rozmowie z Kristą Fleischmann

3 Z. Freud Kultura jako źródło cierpień, przeł. J. Prokopiuk, Aletheia, Warszawa 2013, s. 23-24.

4 Tamże, s. 24.

5 Tamże.

6 Zob. o tym także A. Bielik-Robson John Maxwell Coetzee i literatura pustyni, w: Wielcy artyści ucieczek, Ha!art, Kraków 2013.

7 Zob. o tym, P. Jasnowski Georges Perec i praca żałoby , "Pamiętnik Literacki” 2013 nr 4, s. 115-134; tegoż Perec i melancholia. Zarys geografii melancholicznej, "Teksty Drugie” 2014 nr 5, s. 274-293.

8 G. Perec Jesienne gnocchi albo odpowiedzieć na kilka dotyczących mnie pytań, przeł. E. Kuniec, Lokator, Kraków 2012, s. 196.

9 Cyt. za: T. Pindel Biografia. Mario Vargas Llosa, Znak, Kraków 2014, s. 179-180. 
autor Kalkwerk powiedział, w znamienny dla siebie sposób, że każdy człowiek, bez różnicy „potrzebuje płaszcza, bo inaczej zamarznie zimą”; bowiem jak sądził, pozostając wierny Schopenhauerowi, „świat jest swego rodzaju zima"10. Jego bohaterowie trzepoczą się jak ryby w sieci lub, by ująć rzecz jeszcze inaczej, pochwyceni w pajęczą sieć próbują się z niej - oswobodzić. Lecz rozrywając ją, wpadają w inną, odnawiając beznadziejne ten sam gest. Dlatego, by móc dalej wieść swą egzystencję, usiłują się schronić lub zbiec. Austriak nie miał złudzeń i nie podsuwał trwałych rozwiązań, ponieważ te - wiedział to doskonale - nie istnieją. Jego powieściowym dublerom pozostają tylko półśrodki, wyłącznie paliatywy. A palliare z łaciny - dodajmy - to nic innego jak właśnie „okrywać pła s z c z e m”11 (palliatus to okryty greckim płaszczem). Prześledzenie właśnie tych środków i refugiów (jak mawiał Reger w Dawnych mistrzach), z nieustającym odniesieniem do samego pisarza, czynię przedmiotem niniejszego szkicu.

\section{Przyczyna}

Bernhard nigdy „nie miał łatwego dostępu do życia”, był z nim w nieustającej zwadzie. Urodził się jako nieślubne dziecko, nigdy nie poznał swojego ojca. "Ani się o nim nie mówiło, ani też nigdy nikt się nie pojawił"12, powiedział Kriście Fleishmann. Dlatego jako dziecko wmówił sobie, że nigdy go nie posiadał, że nigdy go nie było ${ }^{13}$. Kiedy urodził się jego przyrodni brat Bernhard, przestał być w centrum uwagi. Peter miał być, według pisarza, dzieckiem upragnionym $^{14}$, natomiast on był dzieckiem przypadku, „urodzonym z musu w Holandii"15.

Na jego psychice odcisnął piętno także okres nauki („państwowo-faszystowsko-sadystyczny" system wychowawczy, A, s. 19), który określał najpodlejszym w życiu (A, s. 8). Właśnie gimnazjum stanie się dla niego idealnym

\footnotetext{
10 T. Bernhard Spotkanie, s. 113. skuteczny; półśrodek usuwający objawy, ale nie przyczyny.

T. Bernhard Spotkanie, s. 34 .

Tamże.

„Każdy dzień byłdla niego inscenizacją..."Peter Fabjan w rozmowie z Markiem Kędzierskim, "Kwartalnik Artystyczny" 2009 nr 2 (62) s. 41.

5 T. Bernhard Spotkanie, s. 33.
} 
przykładem, „by przestudiować duchowe wnętrzności całego salzburskiego organizmu" (A, s. 72) - i można dodać - całej wojennej i powojennej Austrii. To właśnie tam, i w czasie rozmów z dziadkiem rozwinie się u niego - nieubłagany i bezwzględny - mechanizm czy, jak powie, „sztuka obserwacji” (A, s. 72, 79).

Wśród przeżyć, które „zadecydowały o całym życiu”, były także sceny wojenne (naloty alianckie), śmierć dziadka (1949), matki (1950) i jego własne cierpienie (mokre zapalenie opłucnej żebrowej o podłożu gruźliczym ${ }^{16}$ ). Dlatego oddany Freumbichlerowi, mógł tylko, ustami swego bohatera, powiedzieć - „Zupełny bezsens, ale musimy przez to przejść” (P, s. 48).

\section{Klozet Europy}

Kiedy Bratanku Wittgensteina narrator zasiada w swoim kącie u Sachera, a bohater Wycinki w uszatym fotelu u Auersbergerów, obaj oddają się tej samej obserwacji, w której Bernhard ćwiczył się od młodości. W Wycince bohater obserwuje dawnych, wstrętnych mu przyjaciół, pod osłoną półmroku panującego w przedpokoju. W istocie, Bernhard zawsze wycofuje się do "przedpokoju” i z dystansu uprawia swoją sztukę „rozbierania na czynniki pierwsze” (W, s. 51). Zaczynając od rodzinnej, „zabójczej ziemi” Salzburga, rozszerza swą bezlitosną krytykę na państwo i społeczeństwo; za sprawą swych dublerów wyrzucając mu m.in.: podłość (np. T, s. 48), bezdusznosśc (A, s. 9), bezlitosność (T, s. 40), zakłamanie (B, s. 25), niepoczytalność (K, s. 26), tępotę (P, s. 15), nikczemność (T, s. 40), bezwstydność (K, s. 26) i obłudę (A, s. 9). Kiedy w Betonie bohater decyduje się opuścić Austrię, powiada o niej - z właściwą sobie przesadą:

Jeśli odejdę, powiedziałem sobie siedząc na żelaznym krześle, wyjdę z tego odrażająco zdezelowanego i po prostu niemożliwie zanieczyszczonego klozetu Europy, powiedziałem sobie. Odchodzę, [...] a to znaczy tyle, co zostawić za sobą kraj, który od lat gnębił mnie jedynie w najbardziej szkodliwy sposób i który przy każdej okazji, obojętnie gdzie i kiedy, jeszcze tylko podstępnie i złośliwie sra mi na głowę. (B, s. 71)

Co istotne, w świecie prozy Bernharda wpływ otoczenia nie pozostaje bez wpływu na jednostkę. Salzburg (czy idąc dalej: Austria) jest chorobą, wrodzoną i wszczepioną (A, s. 10). Jest infekcją, którą - dodajmy - trzeba w sobie 
opanować, w sobie przezwyciężyć. Przerażający stan ducha („wszystko we mnie musiało być przerażajace", T, s. 18) odpowiada przerażającej kondycji kraju („przerażająca sytuacja polityczna”, T, s. 49). Dlatego bohaterowie Bernharda próbują uwolnić się z kleszczowych ujęć jego instytucji. Muszą stawić opór "masowemu obłędowi”, by nie paść ofiarą otępienia (T, s. 144). Bo, jak Koller w Wyjadaczach, nie chcą dać się zagarnąć, wchłonąć - „najpospoliciej unicestwić" (T, s. 145). Poddać się im biernie - powiada Roithamer w Korekcie - to godzić się na „rozwój wstecz” (K, s. 26), to - sugeruje narrator Sutereny pozwolić się wtłoczyć w „sztuczne formy"17 (A, s. 162). Dlatego ich ruch jest ruchem w drugą stronę. W Korekcie Roithamer chroni się przed Altensam (figurą niszczącego dziedzictwa) na Höllerowskiej mansardzie, by tam oddać się bez reszty swemu „dziełu życia” - budowie stożka i jego analizie. Czynią to także, na różne sposoby, inni bohaterowie w Kalkwerk (rozprawa o słuchu), Betonie (biografia), Tak (studia nad antyciałami w przyrodzie) i w Wyjadaczach (studia nad fizjonomią). Ponadto w Wycince (Joana) i Tak (Persjanka) dziełem bohaterek są ich partnerzy. O Joanie narrator Wycinki powie przecież: „uprawiała swoje dzieło sztuki zatytułowane Fryc" (W, s. 82). Obie, co znamienne, poniosą fiasko, popełniając samobójstwo.

\section{Aporie}

A dzieje się tak dlatego, że w świecie Bernharda nie sposób do niczego dojść, niczego osiągnąć (w pełni). Wszystko, nieodwołalnie, zarażone jest „wirusem niemożności i katastrofy"18. Nieustające fiasko czytać można, rzecz jasna, dosłownie; ale w ich klęsce da się dostrzec coś więcej. I to „więcej” właśnie każe czytać Bernharda uważniej. Przegrany (Wertheimer) nie tylko bowiem „przegrywa” muzyczną karierę, ale także - egzystencję ${ }^{19}$. Dlatego, kiedy wykrzyknie: „Muzyczne beztalencia!”, natychmiast doda: „beztalencia egzystencjalne!" (P, s. 55)

Do tego stopnia jesteśmy zarozumiali, by wierzyć, że potrafimy nauczyć się muzyki, a nie jesteśmy nawet zdolni do istnienia, bo nie potrafimy przecież panować [nad istnieniem], to ono nad nami panuje[...] (tamże)

Tym w istocie jest Bernhardowskie "unicestwienie".

Posługuję się tu trafnym określeniem Adama Lipszyca, zob. tegoż Thomas Bernhard: Historia naturalna mózgu, w: tegoż Rewizja procesu Józefiny Ki inne lektury od zera, Sic!, Warszawa 2011, s. 188. 
Człowiek, niezależnie od tego, kim jest i co robi, jest według słów bohatera dyletantem. I choć próbuje umknąć dyletantyzmowi: „ten zawsze nas dościga" (P, s. 87). Bohaterowie Austriaka wchodzą w świat z ufnością, pewnością i wiarą („Swego czasu odczuwałem wszystko jako logiczne, jako oczywiste”; B, s. 117), ale szybko tę ufność i pewność tracą. „Niepewność to sama natura człowieka”, powie Wertheimer w Przegranym (P, s. 127). „Wszelka nauka jest nieskuteczna", pomyśli narrator w Betonie (B, s. 117). To rozpoznanie, z obsesją skończonego dzieła i prawdy czytać można jako inscenizację ponowoczesnej demitologizacji nauki. Rzecz ma się podobnie, jak u pokrewnych Bernhardowi pisarzy, np. Gombrowicza ${ }^{20}$, który krytykował w Dzienniku pewność „zachodniej episteme” („Gdy zasiadają [intelektualiści] na podium i głos zabierają [...] nawet mrugnięciem, nie mogą zasygnalizować, że ich wiedza dziurawa i na chybił trafił... [...] A przecie od tego trzeba by zacząć!"21). Słusznie Michał P. Markowski odczytał tę krytykę „jako unieważnienie epistemologii, a tym samym [...] unieważnienie klasycznego, pokartezjańskiego podmiotu"22. Także u Bernharda to, co logiczne i pewne, musi ustąpić temu, co wątpliwe i bezładne - nieporozumieniu i niepowadze $e^{23}$. Logiczność i czytelność świata ulegają zawieszeniu, a ów stan jest nieustająco inscenizowany. Adam Lipszyc, analizując Zaburzenie, słusznie dostrzegł, że monolog księcia jest w istocie parodią koncepcji „wczesnego” Wittgensteina. W świecie Traktatu (z jego krystaliczną strukturą: faktów, zdań i myśli) jest tylko „jeden umysł, który tworzy sobie myśli, «obrazy faktów» - i daje im wyraz w zdaniach elementarnych"24. U Bernharda, obsesyjny monolog księcia, powiada Lipszyc, odwrotnie, ukazuje „niedostępność tej doskonałej klarowności, której możliwość próbuje sobie wmówić wczesny Wittgenstein"25.

Brak logicznej budowy świata i języka uobecniają także inne powieści. W Kalkwerk, jak zauważył już Jakub Momro, wizja eksperymentu w powieści

20 Na pokrewieństwo Bernharda i Gombrowicza wskazywał M. Kędzierski, tegoż Dawni mistrzowie: Witold Gombrowicz i Thomas Bernhard, "Kwartalnik Artystyczny” 2007 nr 4.

W. Gombrowicz Dziennik 1959-1969, Wydawnictwo Literackie, Kraków 2009, s. 393-394.

M.P. Markowski Czarny nurt. Gombrowicz, świat, literatura, Wydawnictwo Literackie, Kraków 2004, s. 310.

„Myślimy - czytamy w Wycince - tylko takimi niebranymi poważnie poważnymi myślami, by, jak myślę, móc przeżyć" (W, s. 83).

A. Lipszyc Thomas Bernhard..., s. 186. Tamże. 
stanowi epistemologiczną obsesję bohatera i autora ${ }^{26}$. Bohater wyczekuje momentu, w którym „to, co zewnętrzne (świat obiektów), będzie równolegle z tym, co wewnętrzne (światem myśli), i będzie mogło zostać uznane za rzeczywiste"27. W Betonie bohater zadaje kłam czystemu poznaniu i podmiotowi, który „nie ma kłopotu ze światem”, danemu mu w postaci jasnych i wyraźnych idei ${ }^{\mathbf{2 8}}$. Nie bez powodu, gdy bohater powie: „Mówiliśmy wciąż o jasnym umyśle, choć nigdy takiego nie posiadaliśmy" (B, s. 122), złapie się na tym, że nie wie, „skąd to zdanie”, że nie jest jego własne i chyba je przechwycił. U Bernharda nic nie jest dane w sposób oczywisty, sens nie tkwi w świecie, gotowy, by go pochwycić. „Życie samo w sobie, istnienie samo w sobie, wszystko to komunały", powiada narrator Sutereny (A, 178). Czysty sens, czysta prawda - oto, czego nie ma, albo tylko nie sposób tego osiągnąć. Wola prawdy i wola jej artykulacji, powiada Bernhard, nie wiedzie do „danego stanu rzeczy", do królestwa prawdy (A, 120). Opis stanu rzeczy tłumaczy coś, co odpowiada woli prawdy opisującego, ale nie prawdzie, „ponieważ tej niepodobna przekazać" ${ }^{29}$ (tamże). Tak rozprawia się z nią narrator w Suterenie:

Chcemy mówić prawdę, ale jej nie mówimy. Opisujemy coś zgodnie z prawdą, ale opis jest czymś innym niż prawda. Musielibyśmy ujrzeć życie jako stan rzeczy, który chcemy opisać, nigdy jednak, mimo iż bardzo się staramy [...] nie widzimy stanu rzeczy. (A, s. 121)

Próżno skądinąd szukać prawdy i pewności w świecie, skoro bohater nie ma jej nawet w sobie. Podmiot u Bernharda to podmiot kartezjański à rebours, wywrócony na nice, który utracił nad sobą pełnię kontroli ${ }^{30}$. Wertheimer

26 J. Momro Logiczna składnia obłędu (Wittgenstein, Beckett, Bernhard), "Teksty Drugie” 2013 nr 6, s. 200.

27 Tamże.

Posługuję się wyrażeniem M.P. Markowskiego, tegoż Polityka wrażliwości. Wprowadzenie do humanistyki, Universitas, Kraków 2013. I brzmi tu, dodajmy, bardzo ponowocześnie, uosabiając poniekąd ponowoczesną krytykę prymatu rozumu, kryteriów prawdy i obiektywności.

Lipszyc pisał o tym tak: „Zamiast podmiotu, który przewodniczy swemu światu, sytuując się na jego granicach [...] w przestrzeni Bernharda pozostaje tylko podmiot, który całkowicie stracił panowanie, który istotnie jest sam jeden, ale wobec zaburzenia logicznej klarowności nie może być władcą pola widzenia, lecz wydany jest na pastwę szumów mózgu", A. Lipszyc Thomas Bernhard..., s. 187. 
w Przegranym nie tylko „nad swoją egzystencją [...] nie panował, lecz wręcz sam dał się jej całkowicie zniszczyć" (P, s. 128). Bohater Wymazywania powiada, że tylko powodowany manią wielkości mógłby powiedzieć, że pojął siebie („im więcej zajmuję się sam sobą, tym bardziej oddalam się od własnej prawdy",WR, s. 126). Z kolei w Suterenie narrator sugeruje, że całe życie otaczają nas ludzie, którzy, nic o nas nie wiedzą, choć twierdzą wprost odwrotnie, a jest tak dlatego, że i „my sami niewiele o sobie wiemy” (A, s. 178-179). „Przez całe życie - czytamy - usiłujemy się zgłębić, ciągle jednak dochodzimy do kresu własnych możliwości i rezygnujemy” (tamże). I dalej: „szukamy siebie i nie znajdujemy, chociaż zabiegamy o to tak usilnie" (A, s. 186).

Wobec tego, co napisałem, nie może dziwić status języka w prozie Bernharda. Ten referencjalny, logiczny, dosłowny - nie istnieje. Bohaterowie muszą stwierdzić, że gładka powierzchnia „lustra” nieodwołalnie pękła; dlatego doskonałe, lustrzane odbicie nie jest możliwe. Nie mogliby przyjąć, że zdanie jest, jak chciał „wczesny” Wittgenstein, obrazem rzeczywistości; że ukazuje, jak rzeczy się mają ${ }^{31}$. W odniesieniu do Kalkwerk trafnie Momro pisze o naczelnym problemie referencji niemożliwej. Świat powieści opiera się, powiada, na lingwistycznej niemożliwościn ${ }^{32}$ W istocie językowe aporie wpisane są w każdą nieomal powieść. Lipszyc sugeruje, że w nich właśnie bierze źródło obsesyjność repetycji: „mówiący powtórzeniami ludzie Bernharda nie mogą niczego powiedzieć raz a dobrze, muszą więc zaczynać wciąż od nowa"33. Język okazuje się zwodliwy, a bohaterowie mocują się z nim na różne sposoby. „Dawno już przestałem pytać się o sens słów, które tylko gmatwają wszystko jeszcze bardziej niezrozumiale", czytamy w Suterenie. W Wyjadaczach Goldschmidt, ma sądzić „że [język] składa się przede wszystkim ze słów równych ciężarkom, które nieustannie ściągają myśli w dół do ziemi” (T, s. 175). Język „najbardziej niefortunnie obciąża myśl domagającą się utrwalenia”. Przez co - czytamy - myśli nie mogą objawić się w „całym swoim znaczeniu i prawdziwej nieskończoności”.

L. Wittgenstein Traktat logiczno-filozoficzny, przeł. B. Wolniewicz, PWN, Warszawa 1997, s. 22; W tym sensie można powiedzieć, że Bernhard, jak „późny” Wittgenstein, odrzuca tezy Traktatu o ścisłym, wzajemnym związku między rzeczywistością a językiem, który miałby być po prostu jej obrazem.

Język Kalkwerk, powiada Momro, natrętnie repetetywny "pokazuje, ale nie reprezentuje, w dosłownym tego słowa znaczeniu uzmysławia, ale nie daje się ująć w żaden szereg pojęć", J. Momro Logiczna..., s. 200. 
W opinii Goldschmidta: „Żadna myśl jeszcze nie została oddana w pełni swojej doskonałości i nieskończoności"; i nie zmieni się to, dopóki odtwarzanie myśli będzie zdane na język (T, s. 175). Skądinąd, kiedy Konrad powiada w Kalkwerk, że „słowa stworzono po to, aby poniżyć myślenie"34, trawestuje to, co Myszkin mówi w Idiocie: „Moje słowa nie odpowiadają moim myślom, a to poniża moje myśli" ${ }^{35}$. Choć i one, dodajmy, są wątpliwe, ponieważ świat nie odbija się w lustrze umysłu, a nasza wiedza nie ma statusu myślowej kopii rzeczywistości.

Kłopotliwość języka okazuje się (i często jest) powodem udręki. Język zostaje tu podniesiony do rangi najwyższej: albo ocala, albo rujnuje. Możliwość wyrażenia tego, co się postrzega, może być „najwyższym szczęściem” (K, s. 220). I analogicznie, niezdolność artykulacji, wypowiedzenia się w sposób klarowny, konkluzywny, może być najwyższym nieszczęściem. W Betonie bohater powiada, że zdania „budzą w nas lęk”, a najpierw lęk budzi sama myśl (B, s. 165). Jak temu zaradzić? W Wyjadaczach Goldschmidt sugeruje, że nie pozostaje nic innego, jak na ów impas przystać (T, s. 175). Rzecz w tym, że bohaterom Bernharda nie zawsze się to udaje.

\section{Obłęd i rozpacz}

Nie sposób nie spostrzec, że bohaterowie Bernharda są, wszyscy, mniej lub bardziej, rozstrojeni, psychicznie okaleczeni lub - całkiem wprost - pomyleni, wydani na pastwę (nasilającego się) obłędu. Ale w tym okaleczeniu, wewnętrznym pęknięciu nie są całkiem odosobnieni. Jeśli bowiem - czytamy w Przegranym - przyjrzeć się ludziom dobrze, „to widzi się tylko kaleki, [... ] samych okaleczonych, innych nie ma" (P, s. 38). Niezborność języka i świata, którą rozpoznają (brak spoistości, logiczności i sensu) nie pozostawia ich obojętnym. Bywa, że pcha ich prosto w objęcia obłędu i katastrofy. Zewnętrze warunkuje tu wnętrze, nie ma tu przepaści ${ }^{36}$. W odniesieniu do Zaburzenia doskonale ujął rzecz Adam Lipszyc:

w przestrzeni Bernharda pozostaje tylko podmiot, który całkowicie stracił panowanie, który istotnie jest sam jeden, ale wobec zaburzenia logicznej

T. Bernhard Kalkwerk, przeł. E. Dyczek, M.F. Nowak, Officyna, Łódź 2010, s. 119.

F. Dostojewski Idiota, przeł. J. Gładyś, Zielona Sowa, Kraków 2005, s. 254. 
klarowności nie może być władcą pola widzenia, lecz wydany jest na pastwę szumów mózgu. ${ }^{37}$

Bohaterowie pragną porządku, a odnajdują bezład, chcą spoistości, a znajdują chaos, pragną reguł i prawidel ${ }^{38}$, a rejestrują tylko przypadek (okropny bezsens przypadku), szukają sensu, a muszą stwierdzić tylko bezsens, wyłącznie absurd. W Wycince aktor Burgtheater powiada we wzburzeniu: „Żyjemy wciąż w absurdzie, [...]. Proszę tylko pomyśleć. Że wszystko jest absurdalne. [...] pomyśleć tylko, że absurdalny świat to jedyny prawdziwy świat" (W, s. 168). Sam Bernhard powiedział z kolei: „Życie składa się z jednego pasma

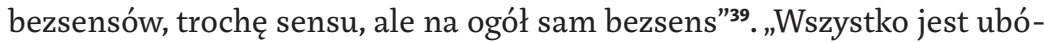
stwem i wiedzie w końcu donikąd"40. Wertheimer powiada podobnie: człowiek wchodząc w świat wkracza, jak sugeruje, w świat nieporozumień:

który musimy znosić jako świat złożony z samych nieporozumień, a potem opuścić za sprawą jednego wielkiego nieporozumienia, śmierć bowiem jest największym nieporozumieniem, stwierdził, pomyślałem. (P, s. 79)

Nieporozumieniem jest np. śmierć Kollera w Wyjadaczach (w efekcie upadku), kończąca jego uporczywą pracę nad niemożliwym dziełem: śmierć, można rzec, nie mniej absurdalna od choroby i śmierci dziadka i matki - od jego własnej choroby.

Bohaterowie, jak już napisałem, przystępują do „dzieł życia” (jak zasiadał do niego Freumbichle), by do czegoś dojść, są zorientowani na myślenie i cel poznawczy. Redukują swą egzystencję do myśli, odcięci w „więziennych pracowniach", w całkowitej izolacji od świata, który mógłby tę c zy s tą myśl tylko naruszyć i zmącić. I czynią tak, dopóki ich to „nie przygniecie, nie przydusi i nie unicestwi” (T, s. 123). Bo u Bernharda „dzieła” takie są - bo muszą być, jak to wykazałem - bezsensowne i bezskuteczne (zob. też, A, s. 150). "Skok” w taką rozprawę, w doskonałe i „ostateczne dzieło” to nieubłagalnie

Pisze o tym Adam Lipszyc w kontekście Wzburzenia, zob. tamże, s. 187.

38 Jedyną drogą, jaką mogą rozpoznać, jest zupełne bezdroże.

39 T. Bernhard Katolicka egzystencja, przeł. M. Kędzierski, „Kwartalnik Artystyczny” 2009 nr 2 (62) S. $22-23$.

40 Tamże. 
„skok w nieskończoną otchłań” (T, s. 165). W Korekcie czytamy, że niepodobna wszystko: „wiecznie przemyślać od podstaw, możemy bowiem w tym dojść do punktu, w którym te nasze własne myśli, uśmiercające nas po kawałku drążące ustawicznie jak wiertła, tak długo będą to czynić, aż nas po prostu uśmiercą" (K, s. 220). Istotnie, „dzieła” rzucają ich w samotność i obłęd. W Betonie siostra powie bratu, który w swym dziele do niczego nie doszedł: „cóż masz z tego, że studiowałeś te wszystkie bzdury, wpędziło cię to w chorobę, jesteś już niemal obłąkany" (B, s. 20). W końcu, na wpół wariując, o ile będą na tyle przytomni, uciekają od tego, co ich przygniata. W opowiadaniu Tak bohater budzi się i zaczyna „bać się tych rozpraw”. Jest w stanie depresji „nasilającej się aż po granice wytrzymałość”; a w tę „bezwyjściowość” popada właśnie „przez absolutną [...] bezwyjściowość swojej pracy" (T, s. 46). Bohaterowie zdani na własny umysł, pogrążają się w lęku, niemocy i rozpaczy. Tkwią w martwym punkcie, spostrzegając, że nie są już zdolni do ruchu (T, s. 47); że - co gorsza - nie są zdolni do „wypowiedzenia choćby jednego spójnego zdania” (T, s. 58). Inni, trawieni lękiem, wydani są na pastwę natręctw, wykonując raz po raz bezsensowne gesty, czując np. natrętną, przymusową potrzebę liczenia, której, wobec odczucia lęku, nie mogą się oprzeć. W ten sposób chorobliwe próbują uzyskać dystans wobec tego, co ich dusi. Obsesyjnie powtarzając ten sam gest: chodzą do przodu i do tyłu, idą nieregularnym krokiem, liczą „aż do granic obłędu" - podobnie, rzec można, jak obsesyjnie Bernhard puszcza w obieg wciąż te same słowa.

Wielu z nich żyje w nieustającej „autospekulacji” (B, s. 116), „w samopotępieniu i [...] w samowyszydzaniu" (B, s. 114). Bohaterowie oddając się obserwacji, potępiają i gardzą innymi, ale najbardziej zaciekle gardzą sobą. W Betonie siostra wykrzyczy bratu: „Gardzisz wszystkim, [...] wszystkim na świecie, wszystkim tym, co sprawia mi przyjemność, gardzisz. A przede wszystkim gardzisz samym sobą" (B, s. 26). W końcu, doprowadzeni do granic obłędu lub rozpaczy bohaterowie czują nie tylko bezsilność, lecz także samotność i obcość - głuchą i przeszywającą:

"Co mnie zdumiewa", powiedział książę, to jednak nie fakt, że wszystko było zawsze tymi szumami w moim mózgu, że te szumy są, ciągle były, ciągle będą, lecz ten przerażający fakt, [...] ani jeden umysł, nigdy nie odnotował tych szumów i nigdy ich nie odnotuje! Nie jest niczym wstrząsającym, że jest tak, jak jest, jedynie to, że ja sam jestem tym, że jedynie mój umysł jest tym, który musi rejestrować wszystko, co przez to jest straszne i zabójcze [...]. Ten fakt jest dla mnie zabójczy, to jest dla 
mnie zabójczy fakt, mianowicie to, że jestem w tym fakcie sam, że sam jestem w tym fakcie". (Z, s. 145-146)

\section{Kloaka i udawanie sensu}

Przypomnijmy scenę z Chtodu. Bohater, siedząc na pniaku, mając przed sobą Heukareck, rozpamiętuje swe życie. Przypomina sobie kolejne kręgi dziecięcego piekła (szkołę, internat, gimnazjum). Wszędzie - roztrząsa - czuł to samo: był przepędzany, upokarzany, wydalany i odtrącany, rzucany w samotność. „Ciągle mnie odprawiano - powiada - nigdy nie przyjęto, nie przygarnięto" (A, s. 302). Siedząc na pniaku, bohater widzi cały absurd egzystencji. Pogardza sobą, że nadal żyje, choć wie jak marne, jak nikczemne jest życie. Co istotne, widzi pusty pokój na końcu mieszkania, gdzie dziadek co dzień o trzeciej nad ranem zasiadał do pracy, nad tzw. dziełem życia. By „wstawać wbrew bezsensowi, pracować i myśleć wyłącznie w bezsensie”. (A, s. 305). Widzi nietknięte ubrania nieboszczyka, jego papiery i notatki, by zapytać w końcu: „Czy teraz ja powinien zasiąść przy tym biurku?” (A, s. 304). I choć waha się, czy ma do tego prawo, to czytelnik wie, że podejmie niepisany testament, że w istocie już go podjął („Ale przecież od samego początku był to także mój system", A, s. 305).

Dziadek, powie narrator Chłodu, „postrzegał świat prawidłowo: jako kloakę [...]. Kloaka miała w pogotowiu piękność natury dla wzroku ostrego [...]. Ale pozostawała kloaką" (A, s. 305-306). Podejmując testament, wnuk-pisarz (Bernhard) będzie zdobywał dowody na słuszność jego słów, tropiąc je wszędzie. I jak on, będzie wstawał wbrew bezsensowi - i w bezsensie, „z najwyższą precyzją, z najwyższą wnikliwością” będzie „udawał sens” (A, s. 305).

\section{Paliatywy}

Jak pisałem, bohaterowie Bernharda muszą uciekać - albo w śmierć (jak Wertheimer i Roithamer, Persjanka i Joana), albo do miejsc, które przyniosą im ulgę, schronienie choćby na chwilę. Szukają „trzeciego”, innego lub rzeczy, które sprawią, że ich egzystencja stanie się znośna, na powrót możliwa. W każdej powieści wykonują rozpaczliwy gest, mający ich przywrócić światu, z którego wypadli, i zagłuszyć jego bełkot, chaos i zamęt ${ }^{41}$. Ustawicznie szukają „ratunku” (np.T, s. 28), „ucieczki” (W), „ocalenia” (T, s. 8) lub „wybawienia”

41 "Czmychnąć i zostawić ten chaos za sobą" (B, s. 93). 
(T, s. 107). Sięgają po „koło” (P, s. 106) albo „środek ratunkowy” (T, s. 82). Zbiegają z domu, dziedzictwa, ojczyzny, ale także od absurdalnych myśli; ponieważ wszyscy uciekają także przed sobą (przed traumatycznym jądrem własnej psychiki). Wystawieni na krytyczne oko „zabójczych instytucji” (A, s. 162), zbiegają, wpadając w pułapkę własnego spojrzenia, równie dręczącego i nieubłaganego. „Jestem obserwatorem samego siebie, naprawdę od lat nieustannie obserwuję samego siebie, jeśli nie od dziesiątków lat, żyję tylko w samoobserwacji i w samo rozważaniu", powiada bohater w Betonie (B, s. 114). Każdy, mówi narrator Sutereny, „zdany jest na samego siebie, jest skazaną na siebie senną zmorą" (A, s. 181). Dlatego np. Glenn Gould w Przegranym nie tyle chce grać na fortepianie, ile się z nim zestroić, pragnie „zostać fortepianem", by uciec od człowieka, którym jest (P, s. 93). Bohaterowie, by żyć dalej, muszą myśl, która ich dławi, odciążyć albo „przesunąć” (B, s. 106), muszą ją zagadać lub rozproszyć. Może to być myśl natrętna lub absurdalna; może to być np. myśl o śmierci, w której „rozpraszaniu”, powiadał Bernhard - ćwiczymy się wszyscy:

Ponieważ mamy pewność, że jedynie zmierzamy ku śmierci, i ponieważ wiemy, co to oznacza, próbujemy opanować wszelkie możliwe środki rozpraszając to rozpoznanie, i dlatego widzimy na tym świecie, o ile dokładniej się przyjrzymy, tylko ludzi zajętych nieustannie i dożywotnio rozpraszaniem. Ten mechanizm, [...] [jest] u wszystkich mechanizmem zasadniczym, [...]. Wszystkich tych ludzi, kimkolwiek by byli, porusza mechanizm rozpraszania myśli o śmierci, nadciągającej tak czy owak, pomyślałem. Wszystko w człowieku jest rozpraszaniem myśli o śmierci. (T, s. 55)

Dublerzy Bernharda uciekają do czegoś lub w coś albo w „przeciwną stronę". Prześledźmy uważnie ich linie ucieczki. Po pierwsze, czasem najdosłowniej: wyjeżdżają, biegną (lub raczej wybiegają), słowem: opuszczają miejsce, które ich dusi („unicestwia”). W Przegranym bohater wyjeżdża z Wiednia i ratuje się Madrytem, w Betonie narrator ocala się Palmą, w Wymazywaniu Rzymem. Jego „ocalenie", wszakże jest niepewne i nietrwałe - jest ocaleniem na ów moment, gdy coś pękło, zostało zahamowane. Ucieka się właśnie po to, by ożywić, by wyzwolić życie tam, gdzie jest uwięzione ${ }^{42}$. Skoro gest ucieczki nie przynosi trwałej zmiany, trzeba go beznadziejnie powtarzać. U Bernharda 
istotniejszy od celu (Palma, Rzym, Madryt etc.) jest sam ruch (z miejsca w miejsce, tam i z powrotem), który sprawia, że dławiący lęk zmniejsza się lub na tę chwilę - znika. Zostać w miejscu, znieruchomieć, to u Bernharda w każdym wypadku śmierć. To z jednej strony depresja lub obłęd (w końcu samobójstwo), a z drugiej - to zastygnąć, zakrzepnąć w jednym kształcie, w krępującej formie (śmierć duchowa).

Drugą linią ucieczki jest u Austriaka Inny. W Tak narrator podejmuje ostatnią próbę „wyratowania się”, biegnąc do handlarza nieruchomości Moritza, by, jak mówi, „odkryć przed nim [...] całą skrywaną przez lata egzystencję”. Niezdolny do „wypowiedzenia choćby jednego spójnego zdania” usiłuje przed Moritzem, ostatkiem sił, zdać z siebie relację. I choć wyczerpuje się ona w mowie, do której handlarz wydaje się nie mieć dostępu, to narrator doznaje „znaczącej ulgi”. Za sprawą opowieści oczyszcza psychikę, opróżniając „wieloletni psychiczny rezerwuar i śmietnik psychiczny”, który przepełnił się. Prawdziwy moment zwrotny następuje wszakże później, gdy monolog przerwie pojawienie się niejakiej Persjanki i jej partnera życiowego, Szwajcara, którzy zachodzą w interesie do Moritza. Bohater wycofany (do siebie) i zamknięty (w sobie), pogrążony w autospekulacji, za sprawą Persjanki i jej historii - na pewien sposób krzyżującej się z jego własną - wraca do świata, z którego wypadł, by powiedzieć: „byłem po prostu szczęśliwy [...] nie musiałem w ogóle zastanawiać się nad sobą [wyróż. - P.J.]". W Betonie bohater, zamknięty w swym "grobowcu”, ,z rozpaczy” próbuje odwiedzić sąsiada, ląduje następnie w Palmie, gdzie poznaje młodą wdowę, Härdtl. Kobieta, za jego namową, dzieli się z nim swą traumą, co, jak obserwuje, uspokaja ją (B, s. 151). Jego z kolei obecność i historia Härdtl wyrywa z własnego piekła. „Rzeczywiście, nieszczęśliwy człowiek od razu jeszcze bardziej ożywia nas na duchu. I nasza choroba, nawet nasza śmiertelna choroba, jest prawie bez znaczenia" (B, s. 168)

Pod wpływem Innego własna myśl ulega przesunięciu, zostaje zaniechana albo staje się bardziej znośna. Niemal każdy bohater, izolując się od ludzi i świata, szuka sobie podobnego. Jego rzeczywistym krewnym jest na ogół człowiek „ślepego zaułka”. W Korekcie Roithamer darzy sympatią „tych najbardziej zepchniętych na margines społeczeństwa” (K, s. 84), tych „najbardziej bezradnych w świecie" (tamże). To im właśnie, ku przerażeniu rodziny, chce powierzyć swą schedę. W Ungenach spadek zostaje przekazany ludziom marginesu ${ }^{43}$. W Wymazywaniu Murau ofiaruje całe Wolfsegg i całą jego okazałość 
jako „absolutnie bezwarunkową darowiznę dla Izraelickiej Gminy Wyznaniowej w Wiedniu" (WR, s. 537). W Przegranym Wertheimera wprost fascynują ludzie nieszczęśliwi, a trafia na nich wszędzie, gdzie są ludzie, ponieważ, jak mawia, „człowiek to samo nieszczęście” (B, s. 73).

Potrzeba obecności i izolacji to elementarne napięcie w świecie powieści Bernharda. Bohaterowie zamykają się w „fortecy",,twierdzy",,grobowcu", nie otwierając drzwi i nie odpisując na listy - nie obcując z nikim. Wertheimer zasłania zasłony z postanowieniem, że ich nie odsłoni; narrator Przegranego „barykaduje się w pokoju” (P, s. 83), wybiegając i krzycząc na każdego, kto przechodzi; w Tak bohater nie wychodzi ze „swojej więziennej pracowni” przez trzy miesiące (T, s. 59). Ale każdy z nich w końcu pęka i musi stwierdzić, że dłużej sam nie może, że dłużej nie da się samemu wytrzymać: „czternastego dnia [Wertheimer] odsłonił zasłony mieszkania przy Kohlmark i jak szaleniec wybiegł na ulicę, spragniony jedzenia i ludzi" (P, s. 34).W Tak, jak pamiętamy, bohater biegnie, na wpół oszalały, do Moritza. W Korekcie Roithamer schodzi do wioski, do chłopskich synów i górników, a w Cambridge zachodzi do narratora, by „w jego towarzystwie ratować się od zwariowania” (K, s. 72-73)

Inny - choć relacje z nim bywają dwuznaczne i naznaczone egoizmem wyrywa „z piekła samotności” (B, s. 30), bywa „ostatnią szansą przeżycia” (P, s. 64), „ratunkiem”, „ostoją" (W, s. 76), ,istotą regenerującą" (T, s. 10), kimś, kto odwodzi bohatera od samego siebie (tamże). Choć u Bernharda bohater jest w zwadzie z innymi, to właśnie w Innym, i przez Innego (także jego słowa i głos), może umknąć piekłu egzystencji.

Wierzyłem - czytamy w Tak - że mogę żyć tylko i wyłącznie swoją pracą, to znaczy pracą naukową, bez czyjejkolwiek obecności, długo, bardzo długo w to wierzyłem, przez wiele lat, a może dziesięcioleci, aż to momentu, gdy przekonałem się, że żaden człowiek nie może żyć tylko i wyłącznie swoją pracą, bez drugiego człowieka. (T, s. 14-15)

Nienawidzimy ludzi, a mimo to chcemy być razem z nimi, ponieważ tylko z ludźmi i tylko pośród ludzi mamy szansę żyć dalej i nie oszaleć. W samotności nie wytrzymujemy zbyt długo, oświadczył Reger, sądzimy, że możemy być sami, sądzimy, że możemy zostać opuszczeni, wmawiamy sobie, że możemy sami dalej żyć, oświadczył Reger, ale to tylko rojenia mózgu. Sądzimy, że obędziemy się bez ludzi, wierzymy wręcz, że obędziemy się nawet bez jednego, jedynego człowieka, i uroiliśmy też sobie, że mamy tylko jedną szansę, tylko wtedy, kiedy jesteśmy sami 
z sobą, ale to są rojenia mózgu. Bez ludzi nie mamy najmniejszej szansy przetrwania. (DM, s. 171-172)

Sam pisarz, ćwicząc się w obserwacji i krytyce (nie oszczędzając nikogo), nie mógł obejść się bez Drugiego. Całe lata powierzał się opiece starszej od siebie kobiecie, której - jak mawiał - zawdzięczał wiele, o ile nie wszystko ${ }^{44}$. Kiedy zmarła, miał powiedzieć bratu: „Teraz ty musisz tu być dla mnie, inaczej nie przeżyję" ${ }^{45}$. Bernhard mizantrop, autor Wycinki, w której zwrócił się przeciw wszystkim, szukał w życiu uznania i miłości ${ }^{46}$. Jeśli Bóg jest miłością i oznacza akceptację - powiedział jego brat - to „Bernhard przez całe życie szukał akceptacji i miłości”, a więc, dodaje „szukał Boga..." 47 .

Ucieczką jest u Austriaka także muzyka, w której pisarz zaprawiał się w młodości, lecz którą musiał porzucić. W Przegranym narrator pisze, że Steinway na którym grał, okazał się dla niego „fortecą” przeciw rodzinie, „bronią” przeciwko światu (P, s. 25). W Betonie bohater powiada: „czym byłoby wszystko bez muzyki”, by dodać znamiennie: „nadal jest to muzyka, która mnie ratuje” (B, s. 115). W Tak, czytamy, ratuje ona przed „niechybną zagładą i unicestwieniem”. (T, s. 82). Bohater podejmuje próby „wyciągnięcia się z depresji Schumannem" (tamże). Muzyka wszakże, którą Bernhard uważał za najwyższą ze sztuk, w świecie powieści często okazuje się nie wystarczać.

Dlatego bohaterowie uparcie powracającą do słów. I chronią się w nich, jak w schowku, przyoblekają nimi, jak ochronną warstwą, wkładają na siebie jak "grecki płaszcz" ${ }^{48}$. Szukają ich, przywołując jak zaklęcie przeciw chaosowi, który chcą rozpędzić, pragną na go chwilę „rozproszyć”. Uciekają się do własnego słowa i głosu, ale nade wszystko: do „cudzogłosu”, do cudzych słów, które - jak pamiętamy - wiele gmatwają, ale ostatecznie są wszystkim, co

44 Chodzi tu o Hedwig Stavianicek, starszą od pisarza o 37 lat, zmarłą w 1984 roku, zob. M. Mittermayer Od świata..., s. 89-90; W Dawnych mistrzach napisał o niej: „Zawsze sądziłem, że muzyka jest dla mnie wszystkim, nieraz też, że filozofia, że wysoka, najwyższa w ogóle literatura, czy po prostu sztuka. Jednakże wszystko to, cała sztuka, czymkolwiek by była, niczym jest wobec tej jednej i jedynej ukochanej istoty", cyt. za: tamże, s. 90.

"Każdy dzień byłdla niego inscenizacją...", s. 62.

46 Tamże.

47 Tamże, s. 63.

48 Zob. wstęp niniejszego artykułu. 
mają. W Wyjadaczach Goldschmidt-księgarz, choć narzeka na towar, który sprzedaje od lat, zawsze znajduje „[...] schronienie w jednym z tych historycznych zdań, które napisał jakiś szalony tak zwany poeta czy myśliciel" (T, s. 174) Są to, relacjonuje narrator, „zdania, pojedyncze zdania, na przykład Novalisa, Montaigne'a, Spinozy, Pascala, których od czasu do czasu się chwyta, by nie przepaść" (tamże). I choć nie uspokoją one całkowicie, to „odwracają uwagę" (W), przesuwając dławiącą myśl. Piszący, których Bernhard, jak Georges Perec, uważał za krewnych, okazują się poręką i odtrutką, a bywa - że ocaleniem (jak pisarz lubił powtarzać) ${ }^{49}$. Nie dziwi więc, że w Korekcie ściany Höllerowskiej mansardy pokryte są cytatami i że pośród nich Roithaimer znajduje "schronienie"; że to za ich sprawą może w ogóle ścierpieć Altensam (symbolizujące niechciane dziedzictwo), „nie rozpadając się na kawałki” (K, s. 270-271).

Bo też bohaterom Bernharda nieustająco grozi rozpad i dekompozycja. Czytanie i pisanie - o czym piszę dalej - jest dla nich ucieczką przed nią, przed zsunięciem się w otchłań, przed pęknięciem nici, które wiążą ich ze światem. A więc, dodajmy, przed depresją, która jest załamaniem symbolicznej relacji ze światem ${ }^{50}$. Czytając i pisząc, bohaterowie (sam Bernhard) próbują usadowić się w przestrzeni symbolicznej ${ }^{51}$, usiłując zasypać otchłanną pustkę. Literatura - przez swoje zagadywanie pustki i kruchy sens, który próbuje ugrać w dookolnym bezsensie - jest odwrotnością depresji, przed którą uciekają bohaterowie. Oba gesty - lekturowy i pisarski - ratują przed (auto)destrukcją, przeglądaniem się w otchłannej pustce, w ciemnej - jak rzekłby Bernhard - kloace. Bowiem ten sam język, który mąci, daje także, jak pisał Barthes: „apotropaiczną siłę, czy też siłę integracji”" ${ }^{2}$ „Dzięki czytaniu przekraczałem otchłanie, i tutaj ziejące o każdej dobie otworem, znajdując w lekturach ratunek przed stanami psychicznego rozbicia" (A, s. 264). To dlatego drzwi biblioteki, które w Altensam były zamknięte, muszą pozostać

49 "Jedyni przyjaciele, jakich posiadam, to umarli, którzy zostawili mi swoją literaturę, żadnych innych przyjaciół nie mam" (B, s. 33), Nie mam żadnych krewnych, mówiłem jej to wielokrotnie, mam jedynie krewnych duchowych, nieżyjący filozofowie są moimi krewnymi" (B, s. 43). J. Kristeva Czarne słońce. Depresja i melancholia, przeł. M.P. Markowski, R. Ryziński, Universitas, Kraków 2007. W tym kontekście zob. np. Wstep Michała Pawła Markowskiego do J. Kristeva Czarne słońce. Depresja i melancholia, Universitas, Kraków 2007, s. XVIII.

52 R. Barthes Dziennik żałobny, przeł. K.M. Jaksender, Teatr Polski we Wrocławiu, Wrocław 2013, S. 189. 
otwarte, a klucz - wyrzucony. To dlatego w ostatniej powieści Bernhard każe powiedzieć swemu alter ego:

Pierwsze, co teraz zrobię, rzekłem do siebie, to wypuszczę zamkniętego w Wolfsegg złego ducha, którego członkowie mojej rodziny, by tak rzec, skazali na dożywotnie więzienie, i nie tylko nie będę już więcej zamykał drzwi szaf z książkami, lecz zostawię je szeroko po wsze czasy otwarte. Klucze wrzucę do głębokiej studni, żeby nikt nigdy nie mógł tych szaf zamknąć, absolutnie nikt. (WR, s. 123-124)

Bez ich zawartości, „byśmy nie wytrzymali, ani ja, ani moja siostra”, czytamy w Korekcie (K, s. 278-279). W Chtodzie bohater w sanatoryjnej bibliotece odkrywa Verlaine'a, Trakla, ale nade wszystko Biesy. Niesłychaność Biesów przydała mu „sił, wskazała drogę, powiedziała, że jestem na właściwej drodze ku wyjściu” (A, s. 345). Ta szalona i wielka literatura, powiada, „poraziła mnie, abym mógł wyj ść stąd jako bohater" (tamże; wyróż. - P.J.). Narrator szuka w sanatorium więcej "takich potworów”, a ponieważ nie może ich znaleźć, usiłuje co rychlej opuścić Grafenhof i szukać ich na wolności (A, s. 346).

Cudze słowa i głos okazują się w świecie Bernharda paliatywem pierwszym. Dlatego, gdy bohater nie ma do nich dostępu: fizycznie (gdy ktoś, jak w Korekcie, wydziera je z rąk) lub psychicznie (kiedy barierą okazuję się umysł), dopada go „morderczy napad lęku” (T, s. 83).

\section{Kreślić kruchą linię sensu}

Zaczyna się zawsze tak samo. Kiedy coś zatyka gardło ${ }^{53}$. Pisze się (a w każdym razie tak pisze Bernhard) właśnie wówczas, gdy coś niepokojąco pęka, wyrzuca z siodła, wytrąca ze świata, kiedy przez szparę naszych zawsze nie dość biegle skonstruowanych światów, wychyla się chaos i bezsens, odmęt i absurd, otchłań, powtórzmy, „ziejąca o każdej dobie otworem” (A, s. 264). Chaos, który, jak mówi Austriak, trzeba za sobą zostawić. Pisze się więc - powtórzmy jeszcze inaczej - gdy ukazuje nam się „czarny nurt”54, ciemna otchłań, którą Bernhard określa ciemną kloaką. Ucieczka przed nią to w ostatecznym

T. Bernhard Spotkanie, s. 9.

By posłużyć się określeniem M.P. Markowskiego, tegoż Czarny nurt. 
rozrachunku - jak u Gombrowicza - ucieczka przed tym, co Freud nazywa Niesamowitym, a Lacan Realnym ${ }^{55}$.

Nie da się znieść Realnego, powiada Markowski w Czarny nurcie, wobec czego - można tylko wokół niego krążyć, można się jakoś z niego wygrzebać, odnajdując punkt zaczepienia, błahy, nieistotny, wokół którego będzie można spleść ratunkową linę sensu wydobywającą z „ciemności absolutnej ${ }^{56}$.

[...] może to być też praktycznie wszystko, co się pojawi przed oczyma, z czego trzeba będzie budować miejsce do zamieszkania. ${ }^{57}$

U Bernharda mamy podobną sytuację. U niego ten, kto patrzy w tę bezdenną otchłań, kto patrzy w kloakę zbyt długo, może w końcu „rzucić się w nią na łeb na szyję” (A, s. 306). Dlatego i tu bohater musi splatać „ratunkową linię sensu”, musi - powtórzmy - „z najwyższą precyzją, z najwyższą wnikliwością” udawać sens (A, s. 305). A wszystko po to, by, jak mówi narrator Tak, egzystencja na powrót wydała się możliwa, nawet jeśli „poczucie nowych możliwości egzystencjalnych nie utrzyma się zbyt długo" (T, s. 56).

Jedną z furtek, konstrukcji pomocniczych, jest w świecie powieści Bernharda pisanie. W Chłodzie. Izolacji, jego alter ego mówi o tym tak:

Już w tym czasie znalazłem ucieczkę w pisaniu, pisałem i pisałem, nie wiem ile, setki, wiele setek wierszy, istniałem tylko wtedy kiedy pisałem, mój dziadek poeta nie żył, teraz ja mogłem pisać, [...] rzuciłem się na poezję ze wszystkich sił, [...] i nawet jeśli te wiersze były bezwartościowe, to znaczyły dla mnie wszystko, nic na świecie nie znaczyło dla mnie więcej, nie miałem nic prócz możliwości pisania wierszy. (A, s. 287)

Nie sposób przeoczyć, że narrator Tak powiada niemal dokładnie to samo. Pod koniec opowieści ujawnia on, że pisze pewien szkic, kreśli jakieś zapiski; i właśnie za ich sprawą to, co dzieje się w jego życiu, staje się jeśli nie jasne, to bardziej znośne. „Pisaniem tego szkicu chciałbym osiągnąć od razu

55 Analiza dzieła Bernharda według psychoanalitycznego klucza nasuwa się nieodparcie. Tu, zwracając uwagę na pomieszczone w dziele Austriaka tropy, ledwie ją sygnalizuje. 
kilka celów, utrwalić wspomnienie o Persjance, a z drugiej strony poprawić swój stan, przedłużyć swoją egzystencję”, i sprawić „,sobie w ten sposób ulgę" (T, s. 85). Ucieczka w pisanie to praca odciążania: odciążania życia, wynajdywania jego nowych możliwości ${ }^{58}$. Kriście Fleischman pisarz powiedział: „Człowiek zawsze ma c o ś, bo jak nagle nie ma niczego, w co może wierzyć, to umiera, prawda?" 59 . Bernhard jest tu podobny do Gombrowicza, który w Dzienniku powiada, że pragnie czegoś, czego mógłby się uchwycić, chce złapać coś, by nie utonąć, pragnie poczuć się względem czegoś (i jest to, jak pamiętamy, np. ręka w Querandi) ${ }^{60}$.

W jednej z rozmów Austriak powiedział (jak jego dziadek), że w życiu ciągle trzeba się oszukiwać, ponieważ „bez oszustw wszystko by się zapadało i niczego by nie było"61. Właśnie owo „nic” - nie coś, chaos - nie ład, bezkształt - nie kształt, i bezsens, a nie sens leży u podstaw pisania. „W gruncie rzeczy, mówi Bernhard, piszę wyłącznie dlatego, że wszystko jest bardzo nieprzyjemne”62. Kiedy przeżywa się przyjemne sytuacje, mówi, „nie można niczego napisać”. A ponieważ rzeczy przyjemnych jest mało, a jeśli są


to u Bernharda uciekać od tego, co osacza i dławi; to pozbywać się ciężaru, który się niesie, przynosząc sobie ulgę, pisać - to znieczulać się, a także uciekać - od pustego, niespełnionego teraz. Dokładnie tak, jak w ostatniej scenie Wycinki:

i biegłem, biegłem i myślałem, że uciekłem od tej potwornej tak zwanej artystycznej kolacji na Gentzgasse, jak uciekłem od wszystkich potworności, i że napiszę o tej tak zwanej artystycznej kolacji na Gentzgasse, nie wiedząc co, po prostu coś o tym napiszę, i biegłem, biegłem i myślałem, że natychmiast napiszę o tej tak zwanej artystycznej kolacji na Gentzgasse, wszystko jedno co, byle zaraz i natychmiast napisać o tej artystycznej kolacji na Gentzgasse, natychmiast, myślałem, zaraz, myślałem wciąż, biegnąc

58 G. Delezue Nietzsche, przeł. B. Banasiak, KR, Warszawa 2000, s. 11.

62 Tamże.

63 Tamże; u Bernharda albo się wariuje, albo pisze, T. Bernhard Katolicka egzystencja, s. 22 
przed śródmieście, zaraz i natychmiast, zaraz i natychmiast, nim będzie za późno. (W, s. 188-189)

Stawką pisania - odwróćmy uprzedni schemat - jest konstruowanie ${ }^{64}$ czegoś, w miejscu gdzie nie ma nic, ładu, gdzie panuje tylko chaos, kształtu, gdzie jest tylko bezkształt - i sensu, w świecie, w którym króluje jego brak. Pisać, ujmijmy to jeszcze inaczej, to wyjść poza czas, a także wynieść poza niego innych. Bohaterowie Bernharda piszą bowiem nie tylko po to, by sobie "ulżyć" (T, s. 85), ale także po to, by utrwalić innych: jak Persjankę w Tak, jak Pawła w Bratanku, jak Schermaiera w Wymazywaniu ${ }^{65}$

skoro on o tym nie mówi, ja kiedyś o tym napiszę, w zaplanowanym Wymazywaniu, pomyślałem, napiszę o Schermaierze, o wyrządzonej mu krzywdzie, o dokonanych na nim zbrodniach. [...] jest moim obowiązkiem opowiedzieć w Wymazywaniu o Schermaierach i zwrócić na nich uwagę niejako w zastępstwie tych wszystkich, którzy nie opowiadają o swoich cierpieniach. (WR, s. 379)

Na ten powtarzający się gest zwrócił uwagę Mittermayer, sugerując, że literatura miała dla niego ocalić to, „co nie przetrwa w obliczu wszechobecnej śmierci"66.

Pisanie wreszcie miało dla Austriaka potencjał dywersyjny i emancypacyjny. Było kreśleniem wokół siebie linii ochronnej: odgradzającej od chaosu, ale także od tych i tego, co nam grozi: instytucji, które glajchszaltują jednostki. To dlatego Kriście Fleishmann Bernhard powiedział, że co prawda siedzi w środku, w przedziale „państwowego młyna”, ale wyskakuje zawsze przed momentem zmiażdżenia ${ }^{67}$. Literatura byłaby więc narzędziem walki, bronią (jak lubią mówić jego bohaterowie), którą wtyka się niczym pręt w obracające się z żelazną precyzją koła, utrzymujące sztywną skorupę systemu - owego mielącego wszystkich młyna, o którym Bernhard pisał w Korekcie.

\footnotetext{
64 Konstruowanie, a nie odnajdywanie, bo sens u Bernharda - jak u ponowoczesnych myślicieli się wytwarza, a nie znajduje w świecie.

65 M. Mittermayer Od świata..., s. 89.

66 Tamże, s. 89.

67 T. Bernhard Spotkanie, s. 109.
} 


\section{Próbować, mimo wszystko}

Od Bernhardowskiej kloaki, od bezdennej otchłani nie ma - jak pisałem całkowitej ucieczki. Nigdy nie uda się jej do końca wyegzorcyzmować ${ }^{68}$. Pozostają tylko zaklęcia: Inny i literatura albo Inny poprzez literaturę - maskujące traumatyczne jądro, które osłabia lub zawiesza relację z rzeczywistością.

$\mathrm{Na}$ świat powieści Bernharda można spojrzeć jak na teatr, który pisarz otworzył na całe życie. Jest on sceną:

ogłupioną setkami tysięcy postaci, przedstawienia poprawiły się od dnia premiery, wymienia się rekwizyty, wyrzuca aktorów, n i e r o z u mi e ją cych granej sztuki [wyróż. - P.J.], tak było zawsze. Każdą z tych postaci jestem ja, wszystkimi tymi rekwizytami ja, dyrektorem ja. (A, s. 181)

Aktorzy są przekonani o bezsensowności komedii, a także tragedii, w której grają. „Nie rozumieją co jest grane, bo także ja sam tego nie rozumiem [wyróż. - P.J.)]" (A, s.182). Ale ciągle próbują od nowa, ponieważ nic innego im nie pozostaje. Usiłują, chwytając się półśrodków, powracać do świata, z którego wypadli, i odbudowywać (lub tylko udawać) sens, który zniknął w bezdennej otchłani.

Ostatecznie sam Bernhard odnajdzie nadzieję w beznadziei i wybierze ucieczkę -nie w śmierć, lecz właśnie w życie - nieustannie usensawiane i odnawiane:

należy zaczynać wciąż od początku i próbować wciąż od nowa, aż uda się przynajmniej raz w przybliżeniu [...] należy próbować wciąż od nowa, choćby to było nie wiem jak jałowe i nie wiem jak potworne i beznadziejne. Mimo skrajnej niepewności najgłębszego zwątpienia musimy podejmować i kontynuować to, co zamierzyliśmy, wiedząc, ż e pew no ści nie ma, a doskonałość jest nieosiągalna. Rezygnując bez próby, kończymy w rozpaczy i ostatecznie jesteśmy zgubieni. Jak każdego dnia musimy się obudzić i podjąć to, co zamierzyliśmy, [...] i nie zniechęcać się przy pierwszych i prawdopodobnie powracających myślach, że to zamierzenie będzie porażką. Przecież poza porażkami nic ni e ma. Mając przynajmniej wolę porażki, idziemy naprzód i w każdej sprawie i we wszystkim musimy mieć przynajmniej wolę porażki, jeśli

68 Podobnie, nadzwyczaj trafnie, pisał w odniesieniu do Gombrowicza MichałP. Markowski, tegoż Czarny nurt. 
nie chcemy pójść na dno od razu, co faktycznie nie może być zamiarem, który nas tu trzyma. (T, s. 30-31)

\section{$* * *$}

Ostatecznie próba, którą Bernhard podjął w młodości, ciągle ją ponawiając, przypomina poniekąd próbę Sartre'owskiego Roquentina. W ostatniej scenie Mdłości, obserwując śpiewającą Murzynkę, Roquentin zastanawia się - jak pamiętamy - czy i on dałby radę uzasadnić swe istnienie, próbując „w innej dziedzinie"69. Byłaby to książka, powieść: gdyż, jak powiada, nic innego nie umie robic ${ }^{70}$. I choć bohater Sartre'a nie ma wielkiej nadziei, jak - dodajmy nie ma jej np. bohater Tak, to czuje się „jak facet zmarznięty do szpiku kości, który jechał wśród zadymki i nagle wszedł do ciepłego pokoju”. Jak ktoś, powiedziałby Bernhard, kto w tę powszechną zimę, zostaje okryty w ochronny płaszcz. O jakiej książce myśli Roquentin? „Powinna być piękna i twarda jak stal i powinna zawstydzać ludzi z powodu ich istnienia”. Dokładnie taka powiedzmy to wprost - jak cała Bernhardowska literatura"1.

69 Bohaterowie Bernharda bezustannie uzasadniają swoje istnienie. „Rzuciłem się na Schonberga, aby się usprawiedliwić, na Regera, na Joachima, ba, nawet na Bacha, tylko po to, żeby się usprawiedliwić, tak teraz rzucam się na Mendelssohna w tym samym celu" (B, s. 56).

70 J.-P. Sartre Mdłości, przeł. J. Trznadel, PIW, Warszawa 1974, S. 241.

71 Tamże, s. 241-242. 


\section{Abstract}

\section{Paweł Jasnowski}

JAGIELLONIAN UNIVERSITY (CRACOW)

The World as a Cloak and Pretending to Make Sense: Palliatives in Thomas Bernhard's Prose

The characters in Thomas Bernhard's prose share a fundamental experience that revolves around chaos and fear as well as an imperative or compulsion to narrate. They search for (partial) remedies in order to survive, and they resort to prostheses and palliatives in their attempts to bring themselves back into the world out of which they have fallen. Bernhard's doubles are always motivated by an instinct of self-preservation. Among the most effective palliatives, it seems, are the Other and literature, or the Other through literature. As the writer has suggested himself, what is at stake in his writing is to neutralize fear and horror, to subdue life's senseless elements, and to construct something in the place where there is nothing, creating order where chaos reigns, form instead of formlessness, and brittle meaning in a world ruled by its absence.

\section{Keywords}

alienation, aporia, Thomas Bernhard, the Real, self and identity 